\title{
PEMBELAJARAN INQUIRING MINDS WHAT TO KNOW BERBANTUAN MULTIMEDIA PADA PELAJARAN BUDIDAYA RUMPUT LAUT
}

\author{
Yustomo Purbo \\ SMK Negeri 1 Pulau Laut Barat Kota Baru Kalimantan Selatan \\ yustomopurbo@gmail.com
}

\begin{abstract}
Abstrak: Penggunaan Pembelajaran Inquiring Minds What To Know Berbantuan Multimedia pada Mata Pelajaran Budidaya Rumput Laut. Penelitian ini bertujuan untuk mengetahui pengaruh penggunaan model pembelajaran Inquiring Minds What to Know berbantuan multimedia interaktif pada materi Teknik Budidaya Rumput Laut Metode Kantong terhadap a) motivasi belajar; b) minat belajar; dan c) pemahaman konsep siswa. Desain penelitian Quasi-Experiment ini adalah Single-Group Time Series. Penelitian ini dilaksanakan di SMK N 1 Pulau Laut Barat, Kalimantan Selatan. Subjek penelitian terdiri atas 20 siswa. Instrumen penelitian yang digunakan untuk mengumpulkan data adalah tes hasil belajar (pemahaman konsep), serta angket motivasi dan minat belajar siswa. Untuk mengetahui adanya pengaruh penggunaan model pembelajaran Inquiring Minds What to Know berbantuan multimedia interaktif terhadap motivasi belajar, minat belajar, serta pemahaman konsep siswa, data dianalisis menggunakan statistik nonparametrik dengan Wilcoxon Match Pair Test pada taraf signifikansi 5\%. Hasil penelitian menunjukkan bahwa penggunaan model pembelajaran Inquiring Minds What to Know berbantuan multimedia interaktif pada materi Teknik Budidaya Rumput Laut Metode Kantong berpengaruh terhadap a) motivasi belajar; b) minat belajar; dan c) pemahaman konsep siswa.
\end{abstract}

Kata kunci: inquiring minds what to know, multimedia interaktif, motivasi dan minat belajar, pemahaman konsep, teknik budidaya rumput laut

\section{INQUIRING MINDS WHAT TO KNOW LEARNING THE MULTIMEDIA AIDED EDUCATION SEAWEED}

\begin{abstract}
Inquiring Minds What To Know Learning The Multimedia Aided Education Seaweed. The study aims to identify the impact of the use of an Inquiring Minds What to Know learning model assisted by interactive multimedia in the subject of Seaweed Cultivation Technique-Net Bag Method on students' a) learning motivation; b) learning interest; and c) understanding of the concept. The design of QuasiExperiment study is Single-Group Time Series. The research was held at SMK N 1 Pulau Laut Barat, South Kalimantan. The research subjects consisted of 20 students. The research instruments used to collect data were a learning achievement test (understanding of the concept), as well as questionnaires of student's learning motivation and interest. To identify the impact of the use of an Inquiring Minds What to Know learning model assisted by interactive multimedia on students' learning motivation, learning interest, and understanding of the concept, the data were analyzed with nonparametric statistical analysis technique by using Wilcoxon Match Pair Test at a significance level of 5\%. The results of study show that the use of active learning of Inquiring Minds What to Know model assisted by interactive multimedia in the subject of Seaweed Cultivation Technique-Net Bag Method could give impact on students' a) learning motivation; b) learning interest; and c) understanding of the concept.
\end{abstract}

Keywords: inquiring minds what to know, interactive multimedia, learning motivation and interest, understanding of the concept, seaweed cultivation technique 


\section{PENDAHULUAN}

Strategi pembelajaran aktif (active learning) dapat mengurangi peran guru sebagai sumber belajar utama secara bertahap dan lebih mendorong siswa untuk berperan aktif. Guru bergeser perannya menjadi fasilitator yang membantu siswa ketika diperlukan, dan siswa dituntut untuk lebih mampu belajar secara mandiri. Lingkungan kelas secara bertahap dibawa ke dalam suasana yang lebih mendorong student centered learning (pembelajaran berpusat pada siswa). Salah satu tipe active learning adalah full class learning. Full class learning merupakan strategi pembelajaran yang dilaksanakan secara total dalam kelas dengan tujuan mengoptimalkan pembelajaran ceramah supaya lebih interaktif. Inquiring minds what to know adalah adalah salah satu model full class learning. Model ini sangat sesuai diterapkan pada pembelajaran dalam kelas dengan bantuan multimedia guna membantu guru menjelaskan materi yang membutuhkan visualisasi, sehingga pembelajaran menjadi lebih menarik dan menciptakan suasana belajar yang menyenangkan bagi siswa.

Pembelajaran teori Teknik Budidaya Rumput Laut merupakan mata pelajaran yang memerlukan visualisasi dalam menjelaskan materi guna memberikan dasar yang kuat untuk mata pelajararan Penerapan Budidaya Rumput Laut. Ketersediaan media dalam proses pembelajaran sangatlah penting dalam upaya merangsang perhatian siswa, sehingga dapat meningkatkan motivasi dan minat belajar, serta mempermudah pemahaman materi pelajaran yang pada akhirnya dapat meningkatkan prestasi belajar. Terutama untuk materi Teknik Budidaya Rumput Laut Metode Kantong yang belum pernah dipraktikkan dalam pembelajaran di SMK Negeri 1 Pulau Laut Barat karena kondisi perairan laut di Kalimantan Selatan tidak cocok dengan metode ini.

Hasil observasi sebelum dilaksanakan penelitian menunjukkan bahwa dalam pembelajaran Teknik Budidaya Rumput Laut guru belum menggunakan multimedia sebagai alat bantu dalam menjelaskan materi (masih bersifat konvensional). Akibatnya, pembelajaran bersifat satu arah (teacher centered). Hal ini menyebabkan pembelajaran bersifat monoton dan menimbulkan suasana membosankan bagi siswa, sehingga mereka terlihat kurang termotivasi dalam mengikuti pembelajaran. Perhatian siswa terhadap materi yang disampaikan oleh guru lewat ceramah tanpa bantuan multimedia kurang mendukung pembelajaran aktif. Hal ini menjadikan minat siswa juga berkurang. Fakta ini menunjukkan bahwa daya tarik siswa untuk mengikuti pembelajaran teori masih rendah sehingga berimbas pada kurangnya pemahaman (penguasaan konsep) siswa.

Berdasarkan uraian tersebut, pembelajaran teori pada mata pelajaran Teknik Budidaya Rumput laut melalui metode ceramah harus tetap dilaksanakan tetapi motivasi dan minat siswa harus tetap dijaga. Salah satu solusinya adalah melaksanakan model pembelajaran inquiring minds what to know berbantuan multimedia interaktif. Penggunaan multimedia interaktif sebagai pendukung presentasi dalam metode ceramah yang terintegrasi dalam strategi pembelajaran ini akan membantu guru mengakomodasi kebutuhan belajar siswa terutama untuk materi Teknik Budidaya Rumput Laut Metode Kantong. 


\section{Permasalahan}

Terdapat beberapa masalah dalam pembelajaran Teknik Budidaya Rumput Laut di SMK N 1 Pulau Laut Barat. Permasalahan tersebut adalah sebagai berikut.

1. Pembelajaran teori cenderung bersifat konvensional dengan ceramah tanpa adanya media berbantuan komputer, sehingga masih bersifat teacher centered (satu arah).

2. Pembelajaran teori Teknik Budidaya Rumput Laut merupakan mata pelajaran yang memerlukan visualisasi, namun dalam pembelajaran belum menggunakan multimedia.

3. Belum tersedianya multimedia pembelajaran interaktif yang dapat mendukung pembelajaran aktif (active learning).

4. Kurangnya motivasi belajar, minat belajar, dan pemahaman konsep siswa yang diajar dengan metode ceramah tanpa bantuan multimedia interaktif.

\section{Landasan Teori}

\section{Pembelajaran aktif (active learning)}

Michael (2006: 160) menyatakan bahwa pembelajaran aktif (active learning) adalah kegiatan yang mewajibkan siswa untuk secara teratur menilai tingkat pemahaman dan keterampilan mereka sendiri dalam memahami konsep atau menangani masalah dalam disiplin ilmu tertentu. Termasuk juga proses menjaga mental siswa, dan sering secara fisik, aktif dalam belajar melalui kegiatan yang melibatkan mereka dalam mengumpulkan informasi, berpikir, dan memecahkan masalah. Lebih lanjut Silberman (2009: 12) menyatakan bahwa mata pelajaran yang menarik mudah diajarkan, namun untuk pelajaran yang membosankan, seringkali hanya dengan metode belajar aktif yang menyenangkan dapat memenuhi kebutuhan siswa dan memotivasi mereka untuk mengusainya. Silberman (2009: 23-25) menambahkan bahwa bekerja dengan kelompok kecil merupakan bagian signifikan dari pembelajaran aktif. Dalam lingkungan belajar aktif, guru hendaknya membangun daya tarik dulu, memaksimalkan pengertian dan ingatan, melibatkan peserta didik selama ceramah, dan memberi penguatan apa yang telah disajikan.

Berdasarkan uraian tersebut, metode belajar aktif yang menyenangkan dapat memotivasi siswa untuk menguasai suatu materi pelajaran yang membosankan. Adapun pembelajaran aktif sendiri merupakan strategi yang melibatkan siswa secara aktif dalam proses belajar. Dalam strategi ini, selain belajar, seorang siswa juga mengajarkan ilmu yang dia dapat pada teman yang memerlukan bantuannya, tentu saja tetap di bawah panduan dan pengawasan guru. Lingkungan belajar aktif adalah tempat di mana guru mampu membuat rencana dan menyusun skenario pembelajaran guna mengakomodasi kebutuhan belajar siswa. Belajar dalam kelompok-kelompok kecil yang disusun secara cermat merupakan bagian signifikan dari pembelajaran aktif.

\section{Pembelajaran model Inquiring Minds What to Know}

Salah satu model pembelajaran kelas penuh (full class learning) adalah Inquiring Minds What to Know. Teknik ini melibatkan dan dirancang untuk sistem kelas, bukan untuk perorangan. Silberman (2009: 104) menyatakan bahwa teknik sederhana ini dapat merangsang rasa ingin tahu siswa dengan mendorong 
spekulasi mengenai topik atau persoalan. Hisyam Zaini, Bermawi Munthe, \& Aryani (2008: 28) menyatakan bahwa siswa cenderung diam ketika diajak untuk membahas materi yang belum terpecahkan pada pertemuan sebelumnya jika diminta untuk menjawab bersama-sama dalam satu kelas.

Berdasarkan uraian tersebut, pembelajaran aktif dalam kelas penuh memerlukan kerjasama guru sebagai fasilitator dan siswa yang aktif berdiskusi dalam kelompok-kelompok kecil untuk memahami atau menyelesaikan masalah terkait materi yang disajikan. Guru seharusnya mampu memaksimalkan pemahaman konsep siswa terhadap materi yang diajarkan dalam pembelajaran kelas penuh (full class learning) meskipun metode yang digunakan untuk mengajar adalah ceramah. Salah satu model pembelajaran ini adalah Inquiring Minds What to Know (membangkitkan rasa ingin tahu). Teknik pembelajaran ini mampu mengaktifkan siswa dengan cara merangsang rasa ingin tahu mereka terhadap materi yang sedang maupun yang akan diajarkan.

\section{Pembelajaran dengan multimedia interaktif}

Mayer (2009: 3) mendefinisikan multimedia sebagai presentasi materi dengan menggunakan kata-kata (verbal form) dan gambar-gambar (pictorial form). Asmani (2011: 243-244) menyatakan bahwa multimedia interaktif dilengkapi dengan beberapa navigasi yang sering disebut dengan Graphical User Interface (GUI), baik berupa icon maupun button, pop-up menu, scroll bar, dan lainnya, yang dapat dioperasikan oleh pengguna untuk sarana browsing ke berbagai jendela informasi dengan bantuan sarana hyperlink. Lebih lanjut
Heni A. Puspitosari (2010: 2-3) menyatakan bahwa presentasi multimedia interaktif lebih memberikan ruang kepada siswa untuk memahami isi presentasi yang disampaikan, karena penyampaian presentasi terdapat operator (guru) sebagai pengontrol jalannya presentasi.

Berdasarkan uraian tersebut, multimedia interaktif atau rich multimedia merupakan media yang mengkombinasikan konten berupa teks/kata-kata, audio/suara, gambar diam, animasi, dan video. Materi pelajaran yang disajikan dalam multimedia interaktif berbasis ceramah mempunyai pendekatan terpusat pada siswa karena mampu merepresentasikan pengetahuan secara verbal (narasi/teks) dan pictorial (grafis/animasi). Multimedia interaktif sangat membantu guru dalam menjelaskan materi pelajaran melakukan presentasi pembelajaran di depan kelas. Presentasi multimedia interaktif lebih memberikan ruang bagi siswa untuk memahami materi pelajaran karena guru bertindak sebagai operator/pengontrol jalannya presentasi.

\section{Motivasi belajar siswa}

Woolfolk (2009: 186), mendefinisikan motivasi sebagai proses internal yang mengaktifkan (membangkitkan), menuntun (mengarahkan), dan mempertahankan perilaku dari waktu ke waktu. Adapun Slavin (2009: 106) menyatakan bahwa motivasi bukan hanya berperan penting dalam mengupayakan siswa terlibat ke dalam kegiatan akademis. Motivasi juga berperan penting dalam menentukan seberapa banyak informasi yang akan diperoleh siswa. Lebih lanjut Woolfolk (2009: 188) menyatakan bahwa motivasi instrinsik (intrinsic motivation) adalah kecenderungan alamiah untuk mencari dan menaklukkan tantangan. 
Adapun motivasi ekstrinsik (extrinsic motivation) adalah kecenderungan kita melakukan sesuatu untuk mendapat nilai yang baik, menghindari hukuman, membuat guru senang, atau alasan lain yang hanya sedikit hubungannya dengan tugas itu sendiri. Dahar (2011: 124) menyatakan bahwa siswa harus diberi motivasi untuk belajar dengan harapan bahwa belajar akan memperoleh hadiah. Misalnya, siswa dapat mengharapkan bahwa informasi tentang suatu pokok bahasan akan memenuhi keingintahuan mereka dan akan berguna bagi mereka atau dapat menolong mereka untuk memperoleh nilai yang baik.

Berdasarkan uraian tersebut, motivasi adalah daya penggerak/kekuatan pendorong yang menjadikan manusia menjadi aktif dalam melakukan sesuatu untuk mencapai tujuan. Motivasi akan membangkitkan, mengaktifkan, dan mengarahkan perilaku seseorang yang menjadikannya mempunyai semangat untuk terus berkembang dari waktu ke waktu. Motivasi belajar mempengaruhi perilaku siswa, waktu belajar, fokus dalam belajar, ketekunan (tidak mudah menyerah) siswa, dan perasaan/rasa percaya diri siswa. Motivasi juga berpengaruh pada kegiatan/aktivitas akademis siswa dan berperan penting dalam menentukan seberapa banyak pengetahuan yang mereka pelajari.

\section{Minat belajar siswa}

Djaali (2007: 121) menyatakan bahwa minat adalah rasa lebih suka dan ketertarikan pada suatu hal atau aktivitas tanpa ada yang menyuruh. Lebih lanjut Woolfolk (2009: 204205) menyatakan bahwa ada dua macam interest (minat) yaitu personal interest (minat individual) dan situasional interest (minat situasional). Personal interest adalah aspek yang bersifat lebih enduring (tahan lama) pada diri seseorang. Adapun situasional interest adalah aspek yang berumur lebih pendek dari aktivitas atau materi yang membangkitkan dan mempertahankan perhatian siswa. Slavin (2009: 132) menyatakan bahwa guru harus berusaha menarik minat siswa mereka terhadap materi pelajaran yang sedang diajarkan dan kemudian menyajikannya dengan cara yang memikat maupun meningkatkan keingintahuan siswa.

Berdasarkan uraian tersebut, minat adalah rasa lebih suka/ketertarikan pada suatu hal/aktivitas tanpa keterpaksaan. Minat akan mempengaruhi perhatian dan hasil belajar siswa. Pemusatan perhatian seorang siswa secara terus menerus terhadap suatu materi pelajaran menjadikan dia lebih aktif belajar daripada siswa lain untuk mencapai prestasi yang diinginkannya. Guru mempunyai peran untuk membangkitkan minat atau rasa ingin tahu siswa yang mendalam untuk menguasai pengetahuan yang mereka ajarkan. Akan lebih baik bila guru mampu mempertahankan minat siswa dalam jangka waktu yang lama, dalam hal ini guru mampu menciptakan pembelajaran bermakna. Tolak ukur keberhasilan proses belajar bukan hanya nilai siswa yang memuaskan, tapi juga kemampuan mereka dalam menerapkan pengetahuan yang diperoleh dalam kehidupan nyata.

\section{Pemahaman konsep siswa}

Winkel (2005: 92) mendefinisikan konsep sebagai satuan arti yang mewakili sejumlah objek yang memiliki ciri-ciri sama. Dahar (2011: 62) menyatakan bahwa konsep merupakan batu pembangun berpikir. Konsep 
merupakan dasar bagi proses mental yang lebih tinggi untuk merumuskan prinsip dan generalisasi. Lebih lanjut Turnbull (2009: $\quad$ 1415) menyatakan bahwa proses belajar terjadi baik pada anak-anak dan orang dewasa, mereka harus membangun pemahaman awal mereka serta membangun atau mengkonstruk kemampuan mereka sendiri yang unik. Adapun (Michael \& Modell (2003: 5) menyatakan bahwa kesalahan dalam memahami (misconceptions) akan mengganggu upaya siswa untuk menyerap pengetahuan baru. Winkel (2005: 92) menyatakan bahwa belajar konsep merupakan salah satu cara belajar dengan pemahaman. Adapun skema konseptual adalah keseluruhan kognitif yang mencakup semua ciri khas yang terkandung dalam suatu pengertian. Woolfolk (2009: 63) menyatakan bahwa alat bantu visual seperti gambar, diagram, atau peta dapat meningkatkan pembelajaran konsep.

Berdasarkan uraian tersebut, proses pembelajaran pada siswa dimulai dengan membangun pemahaman/kemampuan awal mereka. Selanjutnya, sebagai hasil belajar mereka akan terbangun pengertian dari materi yang dipelajari dalam bentuk lisan, tulisan, maupun gambar. Belajar konsep merupakan merupakan hasil utama pendidikan. Dalam hal ini, seorang siswa berusaha atau mampu memecahkan masalah yang dihadapi saat belajar melalui pemahaman konsep-konsep dari materi yang dipelajarinya. Pemahaman konsep siswa dapat lebih ditingkatkan dengan adanya alat bantu visual/media belajar saat penyajian materi pelajaran.

\section{Kajian penelitian yang relevan}

Beberapa hasil penelitian yang relevan dengan penelitian ini adalah sebagai berikut.
Nove Zalikha (2008), hasil penelitiannya menunjukkan bahwa penggunaan multimedia interaktif berpengaruh dalam model active learning tipe True Or False terhadap hasil belajar Biologi siswa. Abidin (2011), hasil penelitiannya menunjukkan bahwa pembelajaran dengan multimedia interaktif efektif dalam meningkatkan minat belajar siswa kelas $\mathrm{V}$ Madrasah Ibtidaiyah Pondok Karanganom Klaten. Dewi Permatasari (2011), hasil penelitiannya menunjukkan bahwa penggunaan multimedia interaktif dapat meningkatkan pemahaman konsep Struktur Bumi siswa kelas V SD Negeri Karang Tengah 3 Sragen. Estu Miyarso (2009), hasil penelitiannya menunjukkan bahwa produk multimedia interaktif pada pembelajaran Sinematografi efektif digunakan untuk pembelajaran dengan kenaikan rerata skor post test atas skor pre test sebesar $14,54 \%$. Data hasil observasi dan wawancara juga menunjukkan bahwa produk ini mampu memotivasi pengguna pada proses pembelajaran.

\section{Kerangka pikir}

Melalui pembelajaran ini, siswa saling bertukar pendapat dan membangun kerjasama positif dalam mendiskusikan pertanyaanpertanyaan atau kasus-kasus yang ditampilkan melalui multimedia. Siswa dipacu untuk mengembangkan potensi otak mereka sebelum diberikan solusi atau jawaban dari kasus atau pertanyaan guru. Siswa diminta mengungkapkan pendapat sebagai tanggung jawab mereka. Dalam kerangka pembelajaran ini, siswa akan merasa terlibat langsung dalam proses pembentukan pengetahuan mereka sehingga akan semakin termotivasi dalam belajar. 
Melalui penerapan model ini, siswa bekerja dalam kelompok atau berpasangan untuk mencapai tujuan belajar. Setiap kelompok tentunya mempunyai pendapat yang berbedabeda tentang suatu kasus atau pertanyaan. Dengan menghormati setiap pendapat siswa dan selalu memacu untuk memberikan pendapat atau jawaban yang rasional dapat mendorong partisipasi dan pengalaman belajar mereka. Penyampaian materi lewat video, gambar, atau foto dapat merangsang semangat belajar siswa terkait esensi materi pelajaran dalam kehidupan nyata dilanjutkan pemberian studi kasus untuk membangkitkan minat mereka agar selalu fokus dalam pembelajaran. Oleh karenanya dapat menciptakan lingkungan belajar yang menyenangkan, terbuka, dan menarik, sehingga dapat meningkatkan minat siswa dalam belajar.

Melalui pembelajaran ini, siswa lebih mudah memahami prosedur pelaksanaan praktik di lapangan dengan ditampilkannya foto-foto, gambar, video, atau animasi yang ditayangkan sehingga visualisasinya lebih jelas tanpa harus mempraktikkan langsung. Dalam diskusi, terjadi proses saling bertukar informasi yang mendorong peningkatan pemahaman siswa terhadap pertanyaan yang diberikan. Pendapat mereka akan ditampung selanjutnya diberi umpan balik dengan jawaban yang benar dan dibahas bersama-sama. Oleh karenanya, pemahaman konsep siswa akan semakin meningkat yang berimplikasi pada meningkatnya hasil belajar.

\section{METODE}

Jenis penelitian ini adalah QuasiExperiment dengan menggunakan desain SingleGroup Time Series, sehingga tidak memerlukan kelompok kontrol. Penelitian ini dilaksanakan di SMK N 1 Pulau Laut Barat, Kabupaten Kotabaru, Propinsi Kalimantan Selatan pada semester genap tahun pelajaran 2011/2012 tanggal 29 April - 1 Juni 2012. Pelaksanaan penelitian diawali dengan pemberian angket motivasi dan minat belajar siswa sebelum diberi perlakuan, pemberian pretest sebanyak tiga kali, pemberian perlakuan (treatment), pemberian posttest sebanyak tiga kali, serta diakhiri dengan pemberian angket motivasi dan minat belajar siswa setelah diberi perlakuan. Subjek penelitian ini adalah siswa kelas X SMK N 1 Pulau Laut Barat, Kompetensi Keahlian Agribisnis Rumput Laut berjumlah 20 orang.

\section{HASIL PENELITIAN}

\section{Pelaksanaan pembelajaran}

Pelaksanaan active learning model inquiring minds what to know yang dilakukan selama penelitian meliputi tahap pendahuluan, kegiatan inti, dan penutup. Dalam setiap tahap tersebut, siswa dilibatkan secara aktif agar suasana pembelajaran lebih menyenangkan dan untuk lebih menggali kemampuan kognitif mereka. Adapun guru menggunakan multimedia interaktif sebagai alat bantu untuk menyampaikan materi dalam bentuk presentasi pembelajaran agar lebih menarik perhatian siswa dan merangsang rasa ingin tahu mereka.

\section{Motivasi belajar siswa}

Berdasarkan hasil analisis diketahui bahwa selisih/peningkatan motivasi belajar siswa setelah pemberian perlakuan adalah sebesar 0,69. Sebelum pemberian perlakuan diperoleh nilai rata-rata motivasi belajar siswa adalah 2,61. Adapun setelah pemberian 
perlakuan diperoleh nilai rata-rata motivasi belajar siswa adalah 3,3. Motivasi belajar siswa sebelum pemberian perlakuan memiliki prosentase sebesar 90\% dengan kategori rendah. Adapun setelah pemberian perlakuan memiliki prosentase sebesar $75 \%$ dengan kategori sedang. Berdasarkan hasil analisis tersebut diketahui bahwa motivasi belajar siswa mengalami peningkatan setelah pemberian perlakuan.

\section{Minat belajar siswa}

Berdasarkan hasil analisis diketahui bahwa selisih/peningkatan minat belajar siswa setelah pemberian perlakuan adalah sebesar 0,80 . Sebelum pemberian perlakuan diperoleh nilai rata-rata minat belajar siswa adalah 3,08. Adapun setelah pemberian perlakuan diperoleh nilai rata-rata minat belajar siswa adalah 3,88. Minat belajar setiap siswa sebelum pemberian perlakuan memiliki prosentase sebesar 55\% dengan kategori sedang. Adapun setelah pemberian memiliki prosentase sebesar sebesar $45 \%$ dengan kategori tinggi. Berdasarkan hasil analisis tersebut diketahui bahwa minat belajar siswa mengalami peningkatan setelah pemberian perlakuan.

\section{Tes hasil belajar (pemahaman konsep) siswa}

Berdasarkan hasil analisis diketahui bahwa selisih/peningkatan pemahaman konsep siswa setelah pemberian perlakuan adalah sebesar 51,68. Pretest (sebelum pemberian perlakuan) diperoleh nilai rata-rata tes hasil belajar siswa 22,25. Pretest pertama diperoleh nilai rata-rata 18,4 ; pretest ke dua 21,5 ; dan pretest ke tiga 26,85. Adapun posttest (setelah pemberian perlakuan) diperoleh nilai rata-rata tes hasil belajar siswa 73,93. Posttest pertama diperoleh nilai rata-rata 67,8 ; pretest ke dua 74,85 ; dan pretest ke tiga 79,15. Sebelum pemberian perlakuan, pemahaman konsep siswa memiliki prosentase sebesar $60 \%$ dengan kategori cukup. Adapun setelah pemberian perlakuan memiliki prosentase sebesar $35 \%$ dengan kategori sangat baik. Berdasarkan hasil analisis tersebut diketahui bahwa pemahaman konsep siswa mengalami peningkatan setelah pemberian perlakuan.

Tabel 1. Hasil Analisis Data Tes hasil Belajar Siswa Sebelum dan Setelah Pemberian Perlakuan (Pretest dan Postest)

Nilai Rata-Rata

\begin{tabular}{cccccc}
\hline \hline & \multicolumn{3}{c}{ Pretest ke- } & \multicolumn{4}{c}{ Postest ke- } \\
\hline $\mathbf{1}$ & $\mathbf{2}$ & $\mathbf{3}$ & $\mathbf{1}$ & $\mathbf{2}$ & $\mathbf{3}$ \\
18,4 & 21,5 & 26,85 & 67,8 & 74,85 & 79,15 \\
\hline \multicolumn{2}{l}{ Rata-Rata: 22,25} & \multicolumn{3}{c}{ Rata-Rata: $\mathbf{7 3 , 9 3}$} \\
\hline
\end{tabular}

PEMBAHASAN

Penggunaan active learning model Inquiring Minds What to Know berbantuan multimedia interaktif

\section{Pelaksanaan pembelajaran}

Pelaksanaan pembelajaran dalam penelitian meliputi tahap pendahuluan, kegiatan inti, dan penutup. Penjelasan tahap-tahap tersebut adalah sebagai berikut.

\section{Pendahuluan}

Pembelajaran diawali dengan guru memberikan apersepsi. Pada pertemuan pertama, guru menjelaskan pentingnya mempelajari materi teknik budidaya rumput laut metode kantong. Adapun pada pertemuan selanjutnya sampai terakhir, 
guru menjelaskan keterkaitan antara materi sebelumnya dengan materi yang akan disajikan pada pertemuan hari itu. Selanjutnya guru menginformasikan SK (Standar Kompetensi), KD (Kompetensi Dasar), indikator pencapaian materi, dan tujuan pembelajaran yang harus dicapai siswa. Selanjutnya, guru meminta siswa untuk menjawab pertanyaan secara individual sedangkan mereka menebak sesuai kemampuan mereka. Semua pendapat mereka ditampung guru, selanjutnya diberi umpan balik dengan menyimpulkan dan mengaitkannya pada materi pelajaran yang akan dibahas pada pertemuan hari itu.

Berdasarkan hasil pengamatan selama penelitian, tanya jawab yang dilakukan guru dengan siswa diberikan kebebasan dalam menebak jawaban terlebih dahulu mampu merangsang keaktifan siswa dalam mengemukakan pendapat. Hal ini dapat memacu motivasi belajar mereka untuk saling berlomba menjawab dengan benar dan menggali kemampuan kognitif siswa sehingga mampu memperkuat pemahaman konsep mereka. Selanjutnya, umpan balik yang diberikan guru terhadap jawaban-jawaban tersebut membuat mereka terlihat lebih bersemangat dan menimbulkan rasa penasaran terhadap materi yang akan dibahas dalam pembelajaran hari itu, terlebih untuk siswa yang mampu menjawab dengan tepat. Hal ini menunjukkan bahwa mereka berminat atau mempunyai rasa ingin tahu yang besar terhadap materi pelajaran yang akan disampaikan guru.

\section{Kegiatan inti}

Pembelajaran dalam tahap ini terdiri atas kegiatan: (a) eksplorasi; (b) elaborasi; dan (c) konfirmasi. Kegiatan eksplorasi dimulai dengan guru membagi siswa menjadi kelompok-kelompok kecil yang heterogen (berdasarkan kemampuan siswa), di mana tiap kelompok berjumlah tiga orang. Hal ini bertujuan untuk melatih kerjasama siswa dengan tim yang berbeda. Pembentukan kelompok belajar ini dilakukan sebanyak dua kali, yaitu pada pertemuan pertama dan keempat (dari enam kali pertemuan pembelajaran). Untuk menyingkat waktu, maka pada pertemuan selanjutnya siswa langsung menempatkan diri dalam kelompok belajar masing-masing sebelum guru masuk kelas dan pembelajaran dimulai. Selanjutnya guru memberikan ilustrasi singkat materi yang akan dijelaskan pada pertemuan tersebut. Dalam penyajian ilustrasi ini ditekankan penggunaan multimedia interaktif berupa skema, gambar, video, atau animasi selain dalam bentuk teks dan suara untuk lebih memperkuat penjelasan materi. Selanjutnya guru memberikan tugas pada tiap kelompok untuk mendiskusikan lebih lanjut sesuai indikator pencapaian materi dan tujuan pembelajaran.

Pembelajaran dilanjutkan pada kegiatan elaborasi. Kegiatan dimulai dengan perwakilan tiap-tiap kelompok belajar mengemukakan pendapat sebagai hasil diskusi mereka. Selanjutnya kelompok lain memberikan tanggapan terhadap pendapat mereka. Selama kegiatan diskusi berlangsung, guru berperan sebagai 
fasilitator (memfasilitasi jalannya komentar dari tiap kelompok belajar) dan motivator (memberikan motivasi agar siswa aktif mengemukakan pendapat). Setelah siswa selesai berdiskusi, guru memberikan umpan balik dengan memberikan penjelasan lebih lanjut mengenai hasil diskusi berupa penjelasan jawaban yang benar untuk menghindari kesalahpahaman siswa. Dalam penjelasan materi ini juga ditekankan penggunaan multimedia interaktif seperti pada saat penyajian ilustrasi berupa skema, gambar, video, atau animasi selain dalam bentuk teks dan suara, hanya saja penjelasannya lebih lengkap/detail. Untuk lebih memperkuat pemahaman siswa, guru mempersilahkan bagi siswa yang belum paham untuk bertanya. Selanjutnya untuk lebih memacu keaktifan belajar siswa, guru memberikan kesempatan pada siswa lain untuk memberikan tanggapan/jawaban terhadap pertanyaan tersebut.

Pembelajaran dilanjutkan pada kegiatan konfirmasi. Guru menyimpulkan tanggapan/jawaban siswa tersebut untuk menyamakan persepsi siswa. Selanjutnya Guru dan siswa menyimpulkan materi pembelajaran bersama-sama. Hal ini penting untuk semakin memberi penguatan pemahaman materi.

\section{Berdasarkan hasil pengamatan} selama penelitian, pembentukan kelompokkelompok belajar kecil dengan anggota yang heterogen ini mampu mengaktifkan anggota setiap kelompok. Siswa yang kurang pandai dapat bertanya pada siswa yang lebih pandai dalam kelompok masingmasing bila merasa belum jelas terhadap materi pelajaran yang disampaikan guru. Dalam hal ini tercipta suasana belajar dan mengajar sesama anggota kelompok. Hal ini terlihat jelas saat ada penugasan dalam diskusi. Selama berdiskusi, mereka saling memberikan penjelasan pada teman satu kelompok bila belum memahami pertanyaan maupun materi yang sedang dibahas. Selain itu, mereka juga saling memberikan dorongan/motivasi dan kesempatan untuk mengemukakan pendapat pada teman dalam satu kelompok. Penggunaan multimedia interaktif dalam penyajian ilustrasi dan penjelasan lebih lanjut mengenai hasil diskusi terlihat mampu meningkatkan daya tarik atau antusiasme serta pemahaman konsep siswa terhadap materi yang akan disampaikan. Hal ini menunjukkan bahwa motivasi belajar, minat belajar, dan pemahaman konsep siswa semakin meningkat.

\section{Penutup}

Pembelajaran dilanjutkan dengan kegiatan penutup. Guru memberikan tugas individual pada siswa untuk merangkum materi pelajaran pada hari itu dan dikumpulkan pada pertemuan selanjutnya. Hal ini penting untuk mengetahui tingkat pemahaman siswa terhadap materi pelajaran yang baru saja dibahas. Selain itu, guru meminta siswa mempelajari kembali materi tersebut di luar jam pelajaran dan mengkajinya dari berbagai sumber belajar, baik dari buku pelajaran, informasi dari teman/orang lain, internet, dan lain-lain, serta mempelajari terlebih dahulu materi yang akan dibahas pada pertemuan 
selanjutnya. Terakhir, guru mempersilahkan siswa kembali ke tempat duduk masing-masing.

Berdasarkan hasil pengamatan selama penelitian, tugas individual siswa untuk merangkum materi pelajaran di setiap pertemuan dapat memacu keaktifan siswa untuk semakin tekun dalam belajar. Hal ini terlihat dari hasil pekerjaan siswa yang dikumpulkan, di mana setiap siswa terlihat berusaha mengerjakan dengan baik. Hasil pekerjaan itu juga menunjukkan adanya motivasi mereka untuk berusaha dengan optimal dalam memahami materi. Hal ini akan berimbas pada peningkatan pemahaman konsep dan minat belajar siswa untuk semakin memperdalam rasa keingintahuan mereka pada materi selanjutnya.

\section{Peningkatan motivasi belajar, minat belajar, dan pemahaman konsep siswa}

\section{Peningkatan motivasi belajar siswa}

Peningkatan motivasi belajar siswa terjadi pada semua komponen penilaian yaitu ketekunan, aktivitas, dan kepercayaan diri. Indikator ketekunan yang pertama adalah keuletan dalam menghadapi kesulitan belajar. Hal ini dapat dilihat dari ketekunan siswa yang sebagian besar langsung mengerjakan tugas maupun soal/pertanyaan yang diberikan guru pada saat pembelajaran. Mereka juga berusaha/memberanikan diri untuk bertanya pada guru atau teman lebih pintar/lebih paham bila merasa sulit memahami materi yang sedang dijelaskan maupun menanyakan kembali soal/pertanyaan yang sulit mereka pahami. Selain itu, siswa juga berusaha aktif dalam berdiskusi untuk menyelesaikan soal/pertanyaan yang diberikan oleh guru saat pembelajaran. Dalam kegiatan diskusi siswa terlihat antusias dalam menyampaikan ide antar anggota kelompok dan kompak dalam pembagian tugas.

Indikator ketekunan selanjutnya adalah kesenangan untuk belajar mandiri. Tolak ukurnya dapat dilihat dari keaktifan siswa dalam mencatat atau merangkum materi pelajaran yang sedang diajarkan oleh guru. Hal ini dibuktikan dengan pengumpulan buku catatan/rangkuman materi pelajaran siswa yang dilakukan setiap kali pembelajaran oleh guru. Di sini terlihat bahwa mereka sudah berusaha melengkapi catatan atau rangkuman materi pelajaran meskipun ada sebagian dari catatan siswa yang kurang dapat dipahami. Selain itu, berdasarkan hasil pengisian angket siswa, setelah perlakuan terjadi peningkatan nilai rata-rata keaktifan siswa dalam membaca rangkuman atau catatan materi pelajaran di rumah (dari 3,35 menjadi 3,8).

Indikator ketekunan yang terakhir adalah berusaha memahami materi pelajaran. Berdasarkan hasil pengamatan, siswa terlihat tekun berlatih mengerjakan/menyelesaikan soal maupun tugas yang diberikan oleh guru dalam dalam pembelajaran, di mana mereka segera mengerjakannya, bukan sibuk dengan melakukan aktivitas lain yang tidak perlu. Selain itu, berdasarkan hasil pengisian angket siswa, setelah perlakuan terjadi peningkatan nilai rata-rata keaktifan 
siswa dalam mempersiapkan materi yang akan dibahas dalam pembelajaran (dari 2,8 menjadi 3,4) serta keaktifan dalam memanfaatkan waktu luang untuk belajar (dari 2,6 menjadi 3,2).

Indikator aktivitas yang pertama adalah kemampuan menyampaikan pendapat. Hal ini dapat dilihat dari keaktifan siswa berpartisipasi menyampaikan pendapat dalam pembelajaran, baik saat diskusi maupun saat guru melempar pertanyaan pada siswa. Selain itu, beberapa siswa terlihat antusias dalam mempertahankan pendapat saat berdiskusi, sehingga diskusi berlangsung lebih hidup dan tercipta suasana pembelajaran yang menyenangkan.

Indikator aktivitas yang ke dua adalah berusaha untuk berprestasi. Tolak ukurnya adalah ketekunan siswa dalam belajar untuk memperoleh nilai tinggi, di mana sebagian besar siswa terlihat mempunyai kemauan yang keras dalam mengikuti setiap kegiatan pembelajaran yang diinstruksikan guru.

Adapun indikator aktivitas yang terakhir adalah kesenangan dalam mencari dan memecahkan masalah. Beberapa siswa lebih aktif mengajukan permasalahan yang mungkin terjadi di lapangan terkait materi pelajaran yang dibahas, sehingga siswa lain terpacu untuk memberikan pendapat dan menguatkan permasalahan tersebut. Selain itu, mereka terlibat aktif dan senang memberikan masukan/analisis terhadap permasalahan/studi kasus dalam diskusi, sehingga mereka termotivasi untuk berdebat mengajukan pendapat sesuai ide mereka.

Indikator kepercayaan diri yang pertama adalah kepercayaan diri karena prestasi. Siswa yang berhasil menjawab soal atau pertanyaan dengan tepat menjadi lebih percaya diri untuk mencoba menjawab pertanyaan berikutnya, baik yang diajukan oleh guru maupun teman sekelas. Selain itu, siswa yang lebih cepat memahami materi pelajaran terlihat lebih percaya diri dari sikap mereka selama mengikuti kegiatan pembelajaran.

Adapun indikator kepercayaan diri yang ke dua adalah kepercayaan diri karena reward. Reward atau penghargaan yang dimaksud bukanlah hadiah namun berupa pujian guru pada siswa yang bisa menjawab dengan tepat dan pemberian motivasi pada siswa yang jawabannya kurang tepat. Hal ini selalu dilakukan guru selama pembelajaran berlangsung agar siswa merasa senang dan tetap menjaga motivasi belajar mereka. Berdasarkan hasil pengisian angket siswa, setelah perlakuan setelah perlakuan terjadi peningkatan nilai rata-rata kepercayaan diri karena mendapat pujian/penghargaan atas prestasi dalam belajar (dari 1,75 menjadi 2,6) serta kepercayaan diri karena mendapat dorongan/motivasi saat belajar (dari 2,85 menjadi 3,65).

\section{Peningkatan minat belajar siswa}

Peningkatan minat belajar siswa terjadi pada semua komponen penilaian yaitu perhatian, perasaan senang, dan ketertarikan. Indikator perhatian yang 
pertama adalah mengikuti proses pembelajaran. Siswa terlihat berkonsentrasi dalam memperhatikan materi pelajaran yang disampaikan guru, bukan melamun. Selain itu, selama guru menyampaikan materi, jarang terlihat ada siswa yang mengantuk. Imbasnya adalah kemampuan mereka dalam memahami materi pelajaran. Hal ini tercermin dari hasil pengisian angket siswa, di mana setelah perlakuan terjadi peningkatan nilai rata-rata kemampuan dalam memahami materi pelajaran saat mengikuti pembelajaran (dari 2,8 menjadi 3,55).

Indikator perhatian yang ke dua adalah mempunyai respon yang baik. Sebagian besar siswa cermat dan teliti dalam memahami serta menjawab pertanyaan/soal/tugas yang diberikan oleh guru. Tolak ukurnya adalah hasil pekerjaan mereka yang dapat dilihat dari tugas/rangkuman materi pelajaran yang dikumpulkan dan kesesuaian jawaban mereka dengan soal yang diberikan guru. Selain itu, mereka mampu mengungkapkan pendapat saat diskusi maupun tanya jawab dengan alasan yang masuk akal.

Indikator perhatian yang ke tiga adalah menunjukkan sikap yang baik. Pada setiap pembelajaran, jarang terlihat ada siswa yang memicu kegaduhan atau membuat suasana kelas menjadi ribut yang menyebabkan iklim belajar kurang nyaman. Berdasarkan hasil pengisian angket siswa, setelah perlakuan terjadi peningkatan nilai rata-rata dari pernyataan "saya membuat gaduh saat pembelajaran" (dari 4,15 menjadi 4,7).
Indikator perhatian yang terakhir adalah menyiapkan diri menghadapi tes/ujian. Berdasarkan hasil pengisian angket siswa, setelah perlakuan terjadi peningkatan nilai rata-rata kerutinan mereka dalam belajar untuk menyiapkan diri menghadapi tes/ujian (dari 3,35 menjadi 3,9) serta kesiapan menghadapi tes/ujian setiap saat (dari 3,25 menjadi 3,7). Hal ini sesuai dengan pengamatan peneliti, bahwa dari pertemuan pertama sampai dengan pertemuan terakhir, mereka terlihat semakin siap secara mental untuk menghadapi tes/ujian.

Indikator perasaan senang yang pertama adalah kehadiran siswa. Sebelum pembelajaran dimulai biasanya siswa sudah siap di dalam kelas (menunggu guru) untuk menerima materi pelajaran. Jarang ada siswa yang memasuki ruang kelas setelah guru memulai pelajaran. Saat pembelajaran berlangsung, jarang juga ada siswa yang meminta ijin untuk ke kamar kecil. Selain itu, dari pertemuan pertama sampai terakhir, tidak ada siswa yang membolos atau meminta ijin untuk pulang.

Indikator perasaan senang yang ke dua adalah pengumpulan tugas. Selama pembelajaran berlangsung, jarang ada siswa yang terlambat dalam mengumpulkan jawaban soal atau tugas dari waktu yang ditentukan guru. Hanya ada sebagian kecil siswa yang terlambat mengumpulkan dan mendapatkan peringatan dari guru.

Indikator perasaan senang yang ke tiga adalah kehadiran guru. Berdasarkan hasil pengisian angket siswa, setelah perlakuan terjadi peningkatan nilai rata-rata 
dari pernyataan "saya tetap berada dalam kelas saat menunggu guru mata pelajaran datang" (dari 3,35 menjadi 3,95) serta pernyataan "saya belajar dahulu saat menunggu guru mata pelajaran datang" (dari 2,3 menjadi 3,35). Peningkatan nilai ini diduga karena guru selalu menginstruksikan siswa untuk mempelajari terlebih dahulu materi pelajaran yang akan dibahas pada pertemuan selanjutnya.

Indikator perasaan senang yang ke empat adalah penerapan metode pembelajaran. Berdasarkan hasil pengisian angket siswa, setelah perlakuan terjadi peningkatan nilai rata-rata dari pernyataan "metode yang dipakai pada setiap pembelajaran menyenangkan" (dari 2,75 menjadi 3,95). Hal ini diduga karena penggunaan multimedia sebagai alat bantu guru dalam menyampaikan materi pelajaran melalui ceramah (presentasi pembelajaran).

Indikator perasaan senang yang terakhir adalah perasaan dalam menghadapi tes/ujian. Berdasarkan hasil pengisian angket siswa, setelah perlakuan terjadi peningkatan nilai rata-rata dari pernyataan "saya merasa senang saat guru mata pelajaran mengumumkan akan diadakan tes/ujian" (dari 2,7 menjadi 3,25) dan pernyataan "saya merasa panik saat mengerjakan soal tes/ujian" (dari 3,45 menjadi 4,05). Berdasarkan hasil pengamatan guru, sebagian siswa terlihat antusias menghadapi ujian. Tingkat kepanikan siswa terlihat semakin menurun diduga karena pelaksanaan tes/ujian yang dilakukan berulang kali, sehingga akan meningkatkan kesiapan mental mereka dari waktu ke waktu.

Indikator ketertarikan yang pertama adalah ketertarikan untuk tahu terhadap materi pelajaran. Berdasarkan hasil pengisian angket siswa, setelah perlakuan terjadi peningkatan nilai rata-rata dari pernyataan "materi yang disampaikan pada setiap pembelajaran menarik" (dari 3,15 menjadi 4) dan pernyataan "saya merasa penasaran/ingin tahu materi belajar selanjutnya" (dari 2,3 menjadi 3,8). Hal ini diduga karena penyajian materi dengan bantuan multimedia, di mana pengetahuan yang disampaikan guru pada siswa dapat dibantu dengan adanya teks, video, animasi, gambar, dan suara yang terkandung dalam media tersebut untuk memperjelas materi pelajaran.

Indikator ketertarikan yang ke dua adalah ketertarikan untuk menyelesaikan tugas. Berdasarkan hasil pengisian angket siswa, setelah perlakuan terjadi peningkatan nilai rata-rata keaktifan siswa untuk berusaha menyelesaikan tugas/soal dengan tepat (dari 3,45 menjadi 4,1). Hal ini diduga karena mulai dari pertemuan pertama, mereka selalu ditekankan oleh guru untuk menyelesaikan tugas maupun soal dengan tepat untuk meningkatkan kompetensi/kemampuan mereka.

Indikator ketertarikan yang terakhir adalah ketertarikan untuk memahami materi pelajaran. Berdasarkan hasil pengisian angket siswa, setelah perlakuan terjadi peningkatan nilai rata-rata keaktifan siswa untuk berusaha memahami materi sebelum dijelaskan dalam pembelajaran (dari 2,45 
menjadi 3,4) dan keaktifan untuk mengulang/memahami kembali materi belajar di rumah (dari 3,15 menjadi 3,3).

\section{Peningkatan pemahaman konsep siswa}

Tes/ujian yang dilakukan berulang kali menyebabkan siswa lebih mudah memahami materi pelajaran terlihat dari peningkatan nilai mereka pada pretest maupun posttest meskipun tanpa pemberitahuan sebelumnya bila akan diadakan tes/ujian ulang sampai tiga kali. Hal ini membuktikan bahwa pemahaman konsep siswa sudah mulai mengalami peningkatan sebelum dilaksanakan active learning model inquiring minds what to know berbantuan multimedia interaktif terhadap materi Teknik Budidaya Rumput Laut Metode Kantong. Setelah dilaksanakan posttest, pemahaman konsep siswa semakin meningkat, terlihat dari nilai rata-rata tes hasil belajar mereka yaitu 73, 93 dibandingkan nilai rata-rata tes hasil belajar mereka pada saat pretest yaitu 22,25 .

Pengaruh penggunaan active learning model inquiring Minds What to Know berbantuan multimedia interaktif terhadap motivasi belajar, minat belajar, dan pemahaman konsep siswa

\section{Motivasi belajar siswa}

Berdasarkan hasil pengujian hipotesis diketahui bahwa penggunaan model pembelajaran ini berpengaruh signifikan terhadap motivasi belajar siswa (terdapat perbedaan signifikan motivasi belajar siswa antara sebelum dan setelah pemberian perlakuan). Strategi pembelajaran aktif dengan model ini dirancang agar tercipta suasana pembelajaran yang menyenangkan, sehingga dapat memotivasi siswa untuk menguasai atau memahami materi pelajaran. Oleh karena itu, pembelajaran disusun dalam kelompokkelompok kecil dengan kemampuan siswa yang heterogen, sehingga tercipta kondisi belajar dan mengajar sesama anggota kelompok saat diskusi.

Guru (peneliti) berusaha memaksimalkan pemahaman dan ingatan siswa dengan melibatkan mereka secara aktif selama pembelajaran. Melalui diskusi, siswa saling bertukar pendapat dan membangun kerjasama positif dalam mendiskusikan pertanyaan-pertanyaan atau kasus-kasus yang ditampilkan melalui multimedia interaktif. Setiap siswa juga saling mendorong anggota kelompok yang lain untuk mengatasi kesulitan belajar bersama-sama, sehingga dengan pembelajaran ini, motivasi belajar siswa akan terpacu untuk terlibat langsung dalam proses pembentukan pengetahuan. Motivasi belajar siswa ini tercermin dalam ketekunan mereka dalam belajar, aktivitas atau kegiatan yang dilakukan saat pembelajaran berlangsung, dan kepercayaan diri yang semakin tinggi.

\section{Minat belajar siswa}

Berdasarkan hasil pengujian hipotesis diketahui bahwa penggunaan model pembelajaran ini berpengaruh signifikan terhadap minat belajar siswa (terdapat perbedaan signifikan minat belajar siswa antara sebelum dan setelah pemberian perlakuan). Dalam pembelajaran, guru berceramah dengan bantuan multimedia untuk menyampaikan materi dalam bentuk teks, gambar, animasi, video, dan suara karena dapat lebih menarik perhatian mereka secara fisik terhadap apa yang guru ajarkan. Hal 
ini dilakukan untuk membangun minat belajar siswa guna memaksimalkan kemampuan mereka dalam mengingat dan memahami materi pelajaran. Selain itu, disajikan juga berbagai macam studi kasus dan pertanyaan-petanyaan yang erat kaitannya dengan aplikasi kehidupan nyata, sehingga mereka merasa bahwa pengetahuan tersebut bermanfaat selain untuk mendapatkan nilai yang bagus juga untuk diterapkan. Hal ini penting untuk membangkitkan minat guna merangsang rasa ingin tahu mereka tentang permasalahan yang sedang dibicarakan atau didiskusikan, termasuk juga kemampuan analisis mereka dan memberikan solusi terbaik yang bisa diterapkan atau sebagai rekomendasi.

Selama pembelajaran berlangsung, guru melibatkan siswa dalam kegiatan kelas untuk meningkatkan kreativitas mereka. Hal ini dilakukan dengan cara memaksimalkan kemampuan/keterampilan mereka dalam berpikir kritis melalui kegiatan diskusi dalam kelompok-kelompok kecil. Secara otomatis, dengan bekerja dalam kelompok kecil membuat mereka saling mendesak anggota kelompok yang lain untuk memberikan kontribusi berupa ide/pendapat yang nantinya akan dibahas bersama-sama dengan kelompok lain.

Hal-hal tersebut dilakukan guru (peneliti) dengan tujuan untuk menarik perhatian siswa, menciptakan rasa senang, dan mampu meningkatkan rasa ingin tahu mereka terhadap materi pelajaran yang disampaikan. Dengan demikian, minat belajar siswa dapat ditingkatkan melalui model pembelajaran ini.

\section{Pemahaman konsep siswa}

Berdasarkan hasil pengujian hipotesis diketahui bahwa penggunaan model pembelajaran ini berpengaruh signifikan terhadap pemahaman konsep siswa (terdapat perbedaan signifikan pemahaman konsep siswa antara sebelum dan setelah pemberian perlakuan). Active learning model inquiring minds what to know berbantuan multimedia interaktif yang dilaksanakan selama penelitian teridentifikasi dapat memberikan perubahan pemahaman konsep siswa terhadap materi pelajaran yang disajikan guru. Melalui pembelajaran ini, proses pertukaran informasi dan pengetahuan sesama siswa terjadi melalui kegiatan diskusi dalam kelompok kecil (tiga orang siswa dalam satu kelompok). Oleh karena itu, diskusi berjalan lebih maksimal dibandingkan mereka bekerja dalam kelompok yang lebih besar. Dalam pembahasan hasil diskusi bersama-sama di kelas, setiap siswa diminta aktif mengemukakan pendapat mereka untuk lebih menghidupkan diskusi dan mampu memberikan kontribusi pada kelompoknya. Setelah diskusi antar kelompok selesai, selanjutnya guru memberikan umpan balik dengan jawaban yang benar, dan siswa secara terbuka diperkenankan memberikan tanggapan maupun pertanyaan. Oleh karenanya akan semakin memperkuat pemahaman konsep siswa terhadap materi yang disajikan sekaligus menghindari adanya kesalahan pemahaman.

Penggunaan multimedia interaktif sebagai alat bantu presentasi pembelajaran guru dengan adanya teks, gambar, suara, video, dan animasi juga lebih memudahkan siswa dalam memahami materi yang disampaikan guru. Tentunya media ini sangat membantu guru dalam meningkatkan rasa ingin tahu siswa yang berimbas pada 
pemahaman konsep siswa. Dalam hal ini, ketika sebuah materi sulit dijelaskan secara teori saja, dengan adanya gambar, video, atau animasi menjadikan visualisasinya lebih jelas. Misal, berbagai peralatan dan bahan dapat disajikan melalui gambar dan video, serta pembuatan konstruksi budidaya dan proses penanaman rumput laut bisa dijelaskan dengan adanya animasi.

Model pembelajaran ini dapat membangun pemahaman awal siswa atau mengkonstruk kemampuan mereka sendiri sehingga tercipta pembelajaran bermakna (memahami konsep lebih mendalam/dapat melekat dalam ingatan dalam jangka waktu yang lama). Dengan demikian siswa mampu menyadari pesan yang disampaikan guru dan memahami hubungan antar materi pelajaran dari pertemuan pertama sampai yang terakhir. Hal ini tercermin dari peningkatan nilai rata-rata hasil belajar mereka baik pada pretest maupun posttest.

\section{KESIMPULAN}

Berdasarkan hasil penelitian dapat ditarik beberapa kesimpulan. Kesimpulan tersebut adalah sebagai berikut.

1. Penggunaan active learning model inquiring minds what to know berbantuan multimedia interaktif untuk menumbuhkan motivasi dan minat belajar serta pemahaman konsep siswa.

a. Pelaksanaan pembelajaran model ini dapat melibatkan siswa secara aktif dengan merangsang keingintahuan mereka melalui bantuan presentasi multimedia interaktif dalam proses pembelajaran. b. Pembelajaran model ini mampu menumbuhkan motivasi dan minat belajar serta pemahaman konsep siswa (setelah pemberian perlakuan: motivasi belajar siswa meningkat dari $5 \%$ menjadi $75 \%$ pada kategori sedang; (2) minat belajar siswa meningkat dari $0 \%$ menjadi $45 \%$ pada kategori tinggi; serta (3) pemahaman konsep siswa meningkat dari $0 \%$ menjadi $35 \%$ pada kategori sangat baik).

2. Berdasarkan pengujian hipotesis didapat hasil sebagai berikut.

a. Penggunaan active learning model Inquiring minds what to know berbantuan multimedia interaktif pada materi Teknik Budidaya Rumput Laut Metode Kantong berpengaruh signifikan terhadap motivasi belajar siswa.

b. Penggunaan active learning model Inquiring minds what to know berbantuan multimedia interaktif pada materi Teknik Budidaya Rumput Laut Metode Kantong berpengaruh signifikan terhadap minat belajar siswa.

c. Penggunaan active learning model Inquiring minds what to know berbantuan multimedia interaktif pada materi Teknik Budidaya Rumput Laut Metode Kantong berpengaruh signifikan terhadap pemahaman konsep siswa. 


\section{SARAN}

Ada dua saran yang peneliti berikan.

Saran tersebut adalah sebagai berikut.

1. Selain penggunaan multimedia interaktif berbantuan komputer dalam pelaksanaan active learning, untuk mengoptimalkan rasa keingintahuan dan keaktifan siswa terhadap materi pelajaran yang dijelaskan dapat dilakukan pemutaran film/video, simulasi, mengundang tamu sebagai pembicara, dan lain-lain.

2. Materi pelajaran perlu disusun secara urut dan logis dalam mengoptimalkan pelaksanaan active learning sehingga siswa lebih mudah dalam memahaminya.

\section{UCAPAN TERIMA KASIH}

1. Rektor Universitas Negeri Yogyakarta

2. Direktur Pasca Sarjana Universitas Negeri Yogyakarta

3. Kaprodi Pendidikan Teknologi Kejuruan

4. Pembimbing Tesis

5. Kepala Sekolah SMKN 1 Pulau Laut Barat

\section{DAFTAR PUSTAKA}

Asmani, J.M. 2011. Buku panduan pemanfaatan teknologi informasi dan komunikasi modern: tips efektif pemanfaatan teknologi informasi dan komunikasi dalam dunia pendidikan. Yogyakarta: Diva Press.

Dahar, R.W. 2011. Teori-teori belajar dan pembelajaran. Jakarta: Erlangga.

Djaali. 2007. Psikologi pendidikan. Jakarta: PT. Bumi Aksara.
Heni A. Puspitosari. 2010. Membuat presentasi multimedia. Yogyakarta: Skripta Media Creative.

Hisyam Zaini, Bermawy Munthe, \& Aryani, S.A. 2008. Strategi pembelajaran aktif. Yogyakarta: Pustaka Insan Madani.

Mayer, R.E. 2009. Multimedia learning: prinsip-prinsip dan aplikasi. (Terjemahan Utomo, T.W.). New York: Cambridge University Press. (Buku asli diterbitkan tahun 2001).

Michael, J. 23 Juni 2006. Where's the evidence that active learning works ?. Advan in Physiol Edu, 30:159-167. Diambil pada tanggal 14 Oktober 2011 dari http://advan.physiology.org/content/30/4/ 159.full.pdf + html

Michael, J.A. \& Modell, H.I. 2003. Active learning in secondary and college science classrooms: a working model for helping the learner to learn. New Jersey: Lawrence Erlbaum Associates, Inc.

Silberman, M. 2009. Active learning: 101 strategi pembelajaran aktif. (Terjemahan Sarjuli, Adzfar Amar, Sutrisno, et al.). Massachusettes: Allyn \& Bacon. (Buku asli diterbitkan tahun 1996).

Slavin, R.E. 2009. Educational psychology: teori dan praktek. (Terjemahan Marianto Samosir). Boston: Allyn and Bacon. (Buku asli diterbitkan tahun 2006).

Turnbull, J. 2009. Coaching for learning: a practical guide for encouraging learning. New York: Continuum International Publishing Group.

Winkel, W.S. 2005. Psikologi pengajaran. Yogyakarta: Media Pribadi.

Woolfolk, A. 2009. Educational psychology: active learning edition. (Terjemahan Soetjipto, H.P. \& Soetjipto, S.M.). Boston: Allyn \& Bacon. (Buku asli diterbitkan tahun 2008). 